\title{
Characteristics and patterns of inappropriate disposal of construction and demolition waste in the municipality of Cabo Frio, Brazil
}

\author{
Características e padrões de disposição inadequada de \\ resíduos da construção e demolição no município de Cabo \\ Frio, Brasil
}

\section{Fernanda Lourenço Campos Fonseca [a] [D], Anderson Amendoeira Namen [a,b] [D]}

How to cite: Fonseca, F. L. C., \& Namen, A. A. (2021). Characteristics and patterns of inappropriate disposal of construction and demolition waste in the municipality of Cabo Frio, Brazil. urbe. Revista Brasileira de Gestão Urbana, v.13, e20200091. https://doi.org/10.1590/2175-3369.013.e20200091

\begin{abstract}
The main objective of this study was to identify and quantify inappropriate disposal of construction and demolition waste (CDW) in Cabo Frio, Brazil. The municipality has areas of environmental preservation and suffers significant environmental impacts due to the large flow of tourists and the inappropriate disposal of CDW. Data collection, carried out from June to September-2019, covered eighteen neighborhoods. 179 inadequate CDW disposal points were detected corresponding to a volume of approximately $448.75 \mathrm{~m}^{3}$. The results were grouped by neighbourhood, kind of disposal place and CDW type. Pareto diagrams were also presented to help define priority neighborhoods for inappropriate disposal reducing actions. There was inappropriate disposal in areas of ecological, landscape or scientific interest, over drainage places, on public roads or sidewalks, and on vacant lots. Besides analysing the disposal characteristics and suggesting actions to solve the problem, a methodology for surveying of inappropriate disposal of CDW was proposed, including a method for the rough calculation of CDW volumes. The development of a smartphone application is another contribution that can facilitate data registration and assist decision making. Although the research focuses on a Brazilian municipality, the same work can be expanded to other municipalities in the world.
\end{abstract}

Keywords: Illegal Waste Disposal. Waste Disposal Mapping. Mobile Application. Environmental Pollution. Waste Management.

\section{Resumo}

O principal objetivo deste estudo foi identificar e quantificar a disposição inadequada de resíduos de construção e demolição (RCD) em Cabo Frio, Brasil. O município possui áreas de preservação ambiental e sofre impactos ambientais significativos devido ao grande fluxo de turistas e ao descarte inadequado de RCD. A coleta de dados, realizada de junho a setembro de 2019, abrangeu dezoito bairros. Foram detectados 179 pontos de disposição inadequada, correspondendo a um volume de aproximadamente $448,75 \mathrm{~m}^{3}$. Os resultados foram agrupados por 
bairro, tipo de local de descarte e tipo de RCD. Também foram apresentados diagramas de Pareto para apoiar a definição dos bairros prioritários para ações de redução de descarte inadequado. Houve disposição inadequada em áreas de interesse ecológico, paisagístico ou científico, em pontos de drenagem, em vias públicas e em terrenos baldios. Além de analisar as características do descarte e sugerir ações para solucionar o problema, propôs-se uma metodologia para levantamento da disposição inadequada de RCD, incluindo um método para o cálculo aproximado dos volumes. $O$ desenvolvimento de um aplicativo para smartphone foi outra contribuição que pode facilitar o registro de dados e auxiliar a tomada de decisão. Embora a pesquisa se concentre em um município brasileiro, o mesmo trabalho pode ser expandido para outros municípios do mundo.

Palavras-chave: Descarte Legal de Resíduos. Mapeamento de descarte de resíduos. Aplicativo Móvel. Poluição Ambiental. Gestão de Resíduos.

\section{Introduction}

The generation of Construction and Demolition Waste (CDW) is a concern in several countries in the world, as it generates different impacts on the environment. In 2012, China, India, United States, France, Germany and United Kingdom were among the largest generators of CDW in the world. However, the problem is worldwide; an analysis carried out in 40 countries, covering the 6 continents, showed that the generation of CDW reached more than 3 billion tons per year by 2012 (Akhtar \& Sarmah, 2018).

In China CDW represents $30 \%$ to $40 \%$ of the total waste generated (Huang et al., 2018). In 2013, the country generated about one billion tons of CDW, which represents five times the amount of Municipal Solid Waste (MSW) generated by the country in the same year (Duan \& Li, 2016), and only $5 \%$ from it were reused or recycled (Huang et al., 2018; Duan \& Li, 2016).

India, in turn, may have generated up to 431 million tons of CDW in 2016, including waste from both rural and urban areas, with rural areas generally generating more waste than urban areas. This fact is justified because the rural population is twice as big as the urban population, although the per capita generation is smaller in the countryside than in the cities (Jain et al., 2018). It should be noted that in India CDW is considered as a part of MSW, which jeopardizes de recycling potential. According to Gulghane \& Khandve (2015), the Indian construction industry does not prioritize the adoption of waste management systems, resulting in huge amounts of material waste every year. Besides, less than $50 \%$ of the CDW generated in India has been reused and recycled, while the rest has been deposited in landfills. In India, waste from major building works is often discarded in roads, which causes traffic jams. Furthermore, small volumes of CDW are discarded together with MSW, which impairs the recycling of both CDW and MSW (Abhijith et al., 2014).

The U.S. Environmental Protection Agency (U.S. EPA) estimated that 548 million tons of CDW were generated in the United States of America (USA) in 2015 (U.S. EPA, 2018). The CDW generated in the country includes construction activities, renovations and demolitions of buildings, roads and bridges. These materials include steel, wood products, plasterboard and drywall, bricks and clay tiles, asphalt tiles, concrete tiles and asphalt concrete (U.S. EPA, 2018).

In France, around 49 million tons of construction waste are generated per year, exceeding the generation of household waste, which reaches 30 million tons annually. Considering the CDW, $49 \%$ are from demolitions, $38 \%$ from renovations and $13 \%$ are new construction. It is estimated that $48 \%$ to $64 \%$ of it is recycled (MCTRACT, 2019).

Between 2004 and 2012, United Kingdom waste generation rates were around 100 million tons per year, exceeding household waste volumes by more than three times and industrial and commercial waste twice in the year of 2012. The United Kingdom produced $1.573 \mathrm{~kg}$ of CDW per capita in 2012, while the European Union (EU) generated $1.638 \mathrm{~kg}$ of CDW per capita in the same year (Defra, 2015). According to Sáez \& Osmani (2019), construction and demolition activities in the EU are responsible for generating 850 million tons of CDW per year. 
In Brazil, the civil construction sector was responsible in 2018 for the generation of 44.53 million tons of CDW, which is equivalent to 122,012 tons/day or $0.585 \mathrm{~kg} /$ inhabitant/day (ABRELPE, 2019). It should be noted that these numbers are underestimated, since ABRELPE data are limited to those reported by the municipalities, and therefore do not represent the total generation. In the state of Rio de Janeiro, where the study was carried out, estimates are that in 2013 approximately 575 thousand tons of CDW were generated per month, $80 \%$ of which were generated in the metropolitan region (PERS, 2013). Rio de Janeiro State Plan for Solid Waste (RJPSW) last version was elaborated in 2013, where the strategies for dealing with CDW were outlined. Actions aiming at the elimination of inappropriate disposal areas, the provision of sorting and recycling centres in the municipalities, the recycling and reuse of CDW, and the implementation of support systems for CDW recovery were included in the document. The deadline for meeting these goals was scheduled for 2014, as recommended by Decree-Law Nr. 7.404 / 2010. However, the planned targets have not yet been fully complied with (PERS, 2013).

Landfilling of CDW increases greenhouse gas emissions, presents public health issues and contributes to the increase of energy consumption (Mah et al., 2018). Moreover, it contributes for the shortening of landfills lifespan (Marzouk \& Azab, 2014). A major concern is that, in general, effective monitoring of CDW illegal dumping is often a difficult task due to the large size of geographic areas to be monitored (Seror \& Portnov, 2018). In Brazil, for example, the municipality of Belo Horizonte is considered a national reference in CDW management, but large volumes of such waste are still destined to landfills, in addition to the occurrence of irregular disposal (Bessa et al., 2019).

The survey, mapping and recording of inappropriate CDW disposal sites may provide information that would assist the implementation of actions to solve the problem. Also, the analysis of the characteristics and patterns of disposal can support the decision making. Hence, a methodology is proposed to simplify the quantitative analysis of the volumes of inappropriate disposals. This method can be replicated by researchers or inspection agents, based on simple training. In addition, from the investigation carried out, a mobile device application was developed to record the information obtained in the field studies. It is believed that these are the greatest contributions of the present work, which was applied in the municipality of Cabo Frio, located in the state of Rio de Janeiro, Brazil.

The rest of the paper is organized as follows. First, a brief literature review is presented which focus on the mapping of CDW illegal dumping. Next, the study methods are introduced and the empirical results are discussed. A software tool to help recording and analysing data is also presented as well as some actions aiming at reducing inappropriate disposals. Finally, some conclusions are presented.

\section{CDW illegal disposals studies}

Some studies deal with the issue of registering and mapping illegal waste discharges. A study on inappropriate disposal of CDW carried out in Parit Raja, Malaysia, focused on the mapping of inappropriate disposal sites, using the Global Positioning System (GPS) on the smartphone (Zainun \& Othman, 2015). The research presented a different methodology for calculating the volume of discarded waste; formulas for calculating the volume of a pyramid or rectangle were used, according to the way the rubble was disposed. To apply the formulas, the lengths and widths of the rubble bases and their heights were measured. For dispersed waste, the amounts were weighed using the kilogram as a unit, and the values were converted into volume $\left(\mathrm{m}^{3}\right)$, based on the density of the discarded material. In this work, the mapping of inadequate disposal sites was done with the aid of ArcGIS geographic information system; 38 places were identified with a total of $934.952 \mathrm{~m}^{3}$ of waste volume (Zainun \& Othman, 2015). Fifteen categories of CDW were observed: plastic, plaster board mixed to tile, concrete mixed to tile, tile, cardboard, rock, metal, bricks, concrete mixed to road pavement, plaster board, concrete, wood, concrete mixed to bricks, mixed construction waste and road pavement. The majority consisted of road pavement with percentages up to $59.97 \%$, followed by mixed construction waste with $18.70 \%$. Concrete with brick and wood had almost the 
same percentage with $6.35 \%$ and $6.14 \%$ respectively. Plastic had the lowest percentage with $0.001 \%$ (Zainun \& Othman, 2015).

The same methodology was applied by Zainun et al. (2016) in the Kluang district, Malaysia, where 64 illegal disposal sites were detected and mapped. Twelve categories of construction waste were identified: concrete, tiles, wood, gypsum board, mix waste, brick and concrete, brick, sand, iron, glass, road pavements, and tile and concrete. The types of construction materials with the highest incidence were analysed, with $54.25 \%$ of mixtures of materials, $20.03 \%$ of concrete and $8.37 \%$ of ceramics (Zainun et al., 2016).

In Haifa, Israel, the mapping of potential areas of inappropriate disposal was carried out using a Geographic Information System and geostatistical modelling. The parameters adopted were the amount of CDW inappropriate discarded and the location of these dumps, considering for the location the distance from the nearest main road, the depth of the ravine present in the place and the proximity of the local forest (Seror \& Portnov, 2018). This study had a preventive focus because, from the identification of possible areas to be used for irregular disposal, the authorities could prioritize specific places for inspection, saving resources and curbing offenders more efficiently. Although not presenting the construction materials categories, the survey showed that $22 \%$ of the CDW sites detected were found close to forest areas, while $57 \%$ of the sites were found less than $1 \mathrm{~km}$ from a main road (Seror \& Portnov, 2018).

A study carried out in Hong Kong aimed to understand the illegal behavior of those involved in inappropriate disposal. 546 trucks suspected of involvement in illegal dumping were identified. To this end, behavioral indicators and updated big data analysis were developed, based on the mining of more than 9 million records of illegal disposal of CDW, collected from 2011 to 2017 (Lu, 2019).

Paz et al. (2018) identified CDW illegal disposal sites in the city of Recife, capital of the state of Pernambuco, Brazil. The geographical coordinates were obtained using a GPS device, and plotted through the Google Earth software. The areas were classified according to the type of waste, and other characteristics of each location were considered, such as neighbourhood, existing pavement type, and vegetation, among others. Recyclable materials for non-construction purposes such as wood, metal, paper, cardboard, or cement bags were found in $70 \%$ of the disposal sites. Non-recyclable waste such as organic were found in $47 \%$ of the sites and materials like paints and solvents were found in only $8 \%$. Socioeconomic characteristics were also considered in the study, such as population, number of permanent households, and average family income, in order to correlate the sites of illegal waste disposal with the characteristics of the surroundings.

The inadequate disposal of CDW has been studied in the municipality of Vitória de Santo Antão, also located in the state of Pernambuco, Brazil. In this study, the spatial recognition of the municipality was made through Google Earth Pro, comprising 44 streets located on the banks of the Tapacurá river. The sites of inadequate CDW disposal were recorded and mapped, and the georeferencing was done with the aid of the Etrex Vista Garmin equipment. The majority of occurrences were from small reforms with materials like land from earthworks, bricks, blocks, tiles, facing boards, mortar and concrete, and precast concrete parts like blocks and tubes. Gypsum was also found. The researchers considered that the discards were irregular due to being close to works that did not have a technician responsible for the construction nor registration of the building with the city hall (Lorena et al., 2017).

Another study carried out in the municipality of Humaitá, State of Amazonas, Brazil, focused on the mapping of solid waste disposal sites in 13 neighborhoods, identifying construction waste among these. The methodology adopted consisted of on-site visits with the aid of a motorcycle and the completion of a form whenever an inappropriate disposal was identified. In this form the date of the visit, the address and a reference point were filled out, in addition to collecting the local coordinates with the help of the GARMIN MAP 76 CSI GPS. The author used the GPS TrackMaker PRO 4.8 software to download the data and the QGIS 2.8.2 software to prepare the map containing the identified sites. In this research, a total of 63 places of irregular disposal were identified. Construction materials were detected with other kinds of waste, such as organic waste, paper and cardboard, plastic bags, PET bottles, lubricating oils, tires, pruning remains and old furniture (Cruz et al., 2017). 
As can be noted, all the reported studies used geo-informatics tools to map inappropriate disposal areas. However, as far as the authors are aware, no study so far attempted to create a methodology which could simplify the calculation of the inappropriate disposals' approximate volumes as well as a software tool to facilitate the recording of information. In the next sections, these tasks will be focused.

\section{Material and methods}

\section{Study Area}

The study was carried out in the city of Cabo Frio, located in the state of Rio de Janeiro, due to the importance of its environmental preservation areas. The municipality has a large flow of tourists (Costa et al., 2017; BRASIL, 2018) which implies a considerable increase in the inadequate disposal of solid waste, including CDW (Schuindt et al., 2018; Bertucci et al., 2016). The study was limited to the central area of the headquarters district, due to its great tourist relevance.

Cabo Frio presents, according to the RJPSW, a per capita CDW generation of $0.90 \mathrm{~kg} /$ inhabitant / year, with an estimated quantity of $126.44 \mathrm{t} /$ day (SEA, 2013). The municipality is home to important Environmental Conservation Units, containing biodiversity from endangered coastal ecosystems, such as Environmental Preservation Areas (EPA). It also has municipal and state parks and Permanent Protection Areas (PPA), protected by state law, based on the premises of the Law on the Protection of Native Vegetation, such as the dunes and lagoons, as shown in Figure 1 (Costa et al., 2017). The object of the present study is limited to the urban macrozone 1, located in the headquarters district of Cabo Frio (PMCBF, 2006). This macrozone is delimited by areas of ecological, landscape and scientific interest, such as Araruama lagoon, Siqueira beach, Palmeiras beach, Palmer canal, Itajuru canal, São Bento beach, Forte beach and the Dunes. This central region has the highest population density in the municipality $\left(6,666\right.$ inhabitants $\left./ \mathrm{km}^{2}\right)$, and houses the historic center, in addition to some of the main beaches of Cabo Frio. These characteristics influence the flow of tourists in the region and the consequent rise of buildings and renovations encouraged by the real estate market (PMCBF, 2019). For the development of this work, the following neighborhoods located in urban macrozone 1 were chosen: Algodoal, Braga, Centro, Itajuru, Jardim Caiçara, Jardim Excelsior, Jardim Flamboyant, Jardim Olinda, Palmeiras, Parque Burle, Parque Central, Passagem, Portinho, Praia do Siqueira, São Bento, São Cristóvão, Vila Nova e Ville Blanche (see Figure 1). 


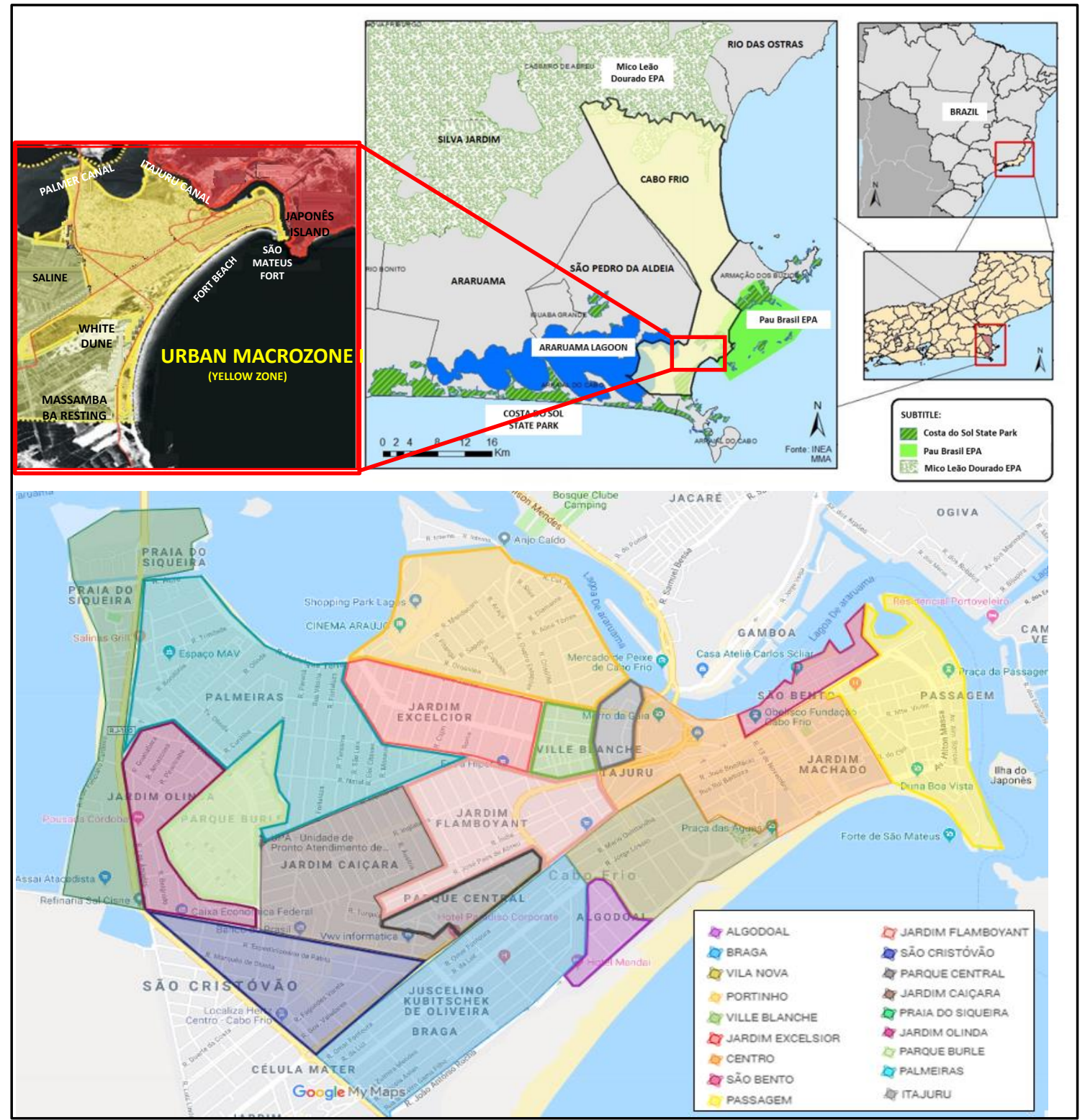

Figure 1 - Details of the study area. Source: The authors (2020).

\section{Data Collection}

Data collection, carried out from June 21, 2019 to September 5, 2019, was conducted based on on-site visits on all streets in the neighborhoods chosen, with the exception of some streets considered at risk, which could involve situations of violence for the researcher (e.g.: places with drug trafficking situations or with high rates of robberies). The addresses excluded by neighborhood were: 1) Braga - Morubá Community (Peralta, 2011): Rua Jediel Firmino dos Santos, Travessa Rufino Aleixo, Travessa Aristides Barbosa Guimarães, Rua Moacir Santos and Rua Santa Helena; 2) Itajuru - Copacabana Community (Peralta, 2011): Rua Sem nome, Rua Copacabana and Rua Leblon; 3) Palmeiras: Rua Lúcio Gonçalves Trindade, Rua Alcir Jorge Veiga and Rua Rondônia; 4) Praia do Siqueira: Rua Sergio Camilo; 5) Jardim Olinda: Travessa Guanabara 2 and Beco Medeiros.

A map of each neighborhood was used to assist in controlling the paths travelled and the streets visited. The map of one of the neighborhoods is shown as an example, showing the route taken with the aid of an automobile (Figure 2). 


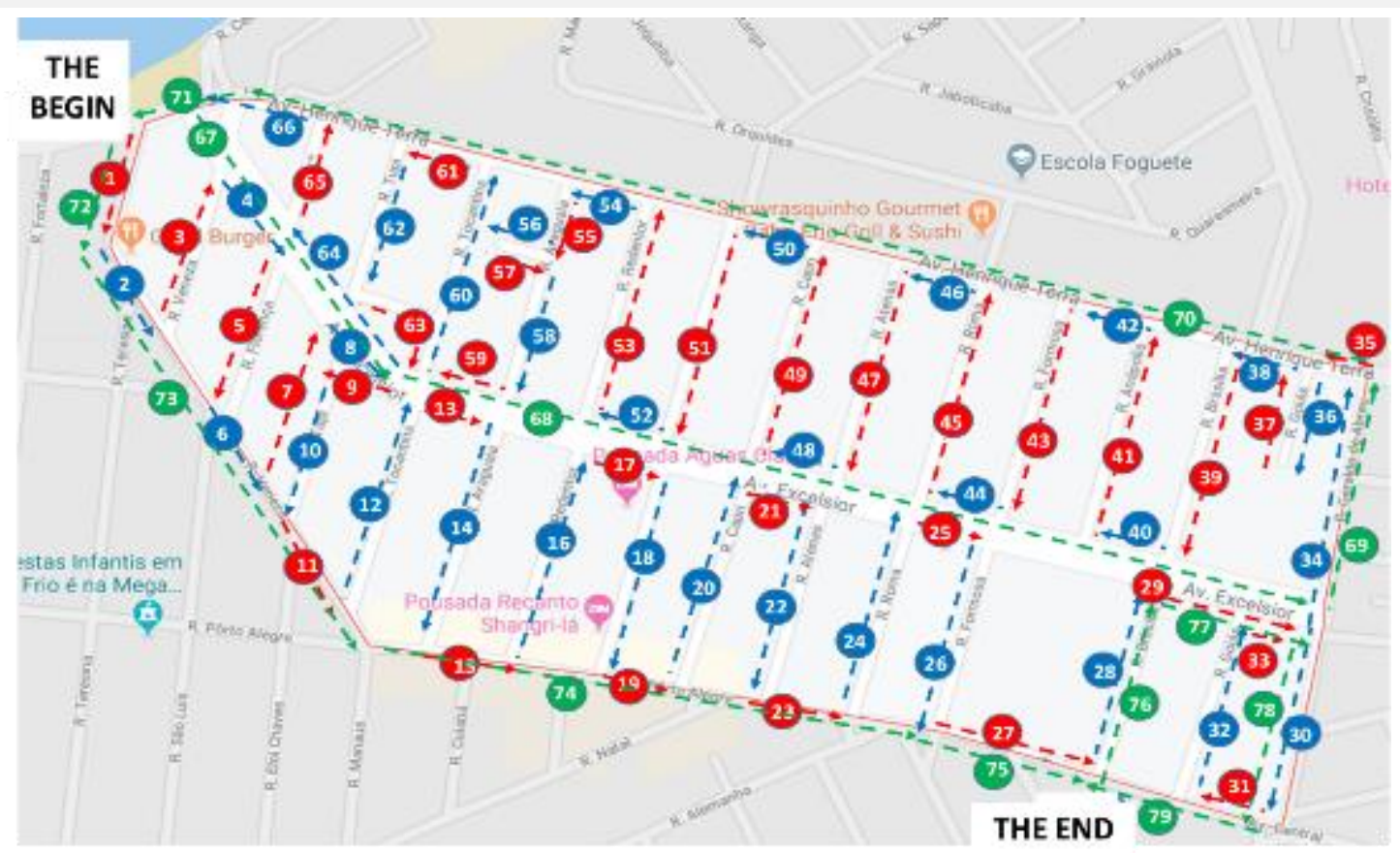

Figure 2 - Route travelled in Jardim Excelsior neighborhood. Note: The route started on the street identified with code 1 and ended on the avenue with code 79. Different colours were used only to facilitate the identification of the number corresponding to each arrow. Source: The authors (2020).

The visits were made by car, in the afternoon, on different days of the week, with an average duration of 4 hours per day. The following procedure was adopted during the visitation: the streets were observed one by one, following the map, in order to cover the entire area of the neighborhood. When a disposal was identified, its georeferenced location was marked with the aid of GPS. The image and other information regarding the disposal were recorded, such as the date of registration, the address, the estimated volume, the characteristics of the disposal site, the classes and composition of the discarded materials. The registration of each identified disposal site lasted an average of 5 minutes.

Due to the impossibility of removing and measuring the volume of the discarded materials, visual analysis of the photographic records and on-site observations were performed, in order to estimate the discarded volumes of each place. A $5 \mathrm{~m}^{3}$ container was used as a reference. The following measures were considered as volume criteria for each disposal place: $1 / 4$ container or less; $1 / 2$ container; $3 / 4$ container; 1 container and more than one container of CDW. Figure 3a illustrates the container fractionation, where each mark represents the mentioned measures.

For each identified disposal site, the following data were recorded: 1 ) the address containing the street name, the number, the neighborhood, the municipality and the state; 2) the georeferenced location; 3) the date of collection; 4) the image of the waste; 5) the volume specification (quantity of containers); 6) the characteristic of the disposal site: if the disposal was close to a drainage location; if the disposal was done on a public road or sidewalk; whether the disposal was made in vacant land and whether it was an area of ecological, landscape or scientific interest, in addition to the description of the area of interest (e.g. mangrove vegetation, dune, São Bento beach, Siqueira beach, Sambaqui1, Palmer canal, Araruama lagoon, etc); 7) the type of waste, based on Resolution 307/2002 of the National Environment Council of Brazil (CONAMA, 2002), which defines waste as being recyclable as aggregate (Class A), recyclable for other uses (Class B), non-recyclable (Class C), and hazardous (Class D). When distinct residues of these types were detected, they were classified as Others. The materials identified for each class were also described, being:

\footnotetext{
1 Prehistoric accumulation of marine, fluvial or terrestrial mollusks carried out by Indians, in which human bones, stone objects, horn and ceramics are often found.
} 
for Class A, the soils, ceramics, concrete, mortar and precast concrete parts; for Class B, plastics, paper, cardboard, glass, wood, metals, plaster and empty paint packaging; for Class $\mathrm{C}$, materials without recycling or recovery technology; for Class D, paints, solvents, oils, asbestos, radiological or industrial residues; for Others, the waste from pruning, household waste, unserviceable, among others.

The form presented in Figure $3 \mathrm{~b}$ was used as an aid to record the information.

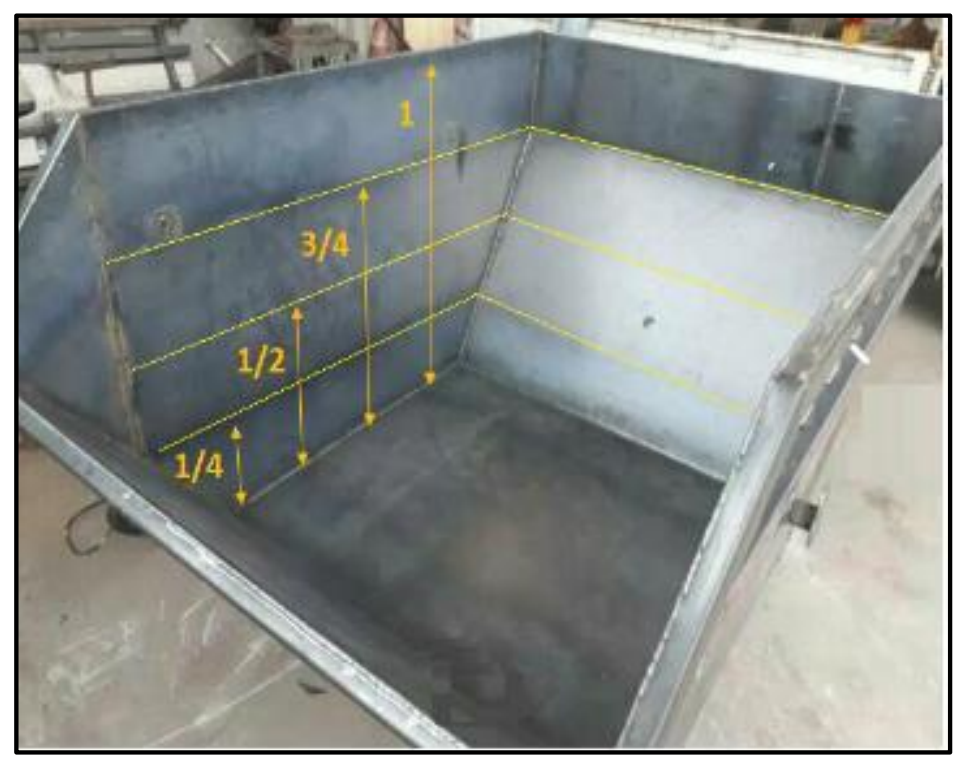

(a)

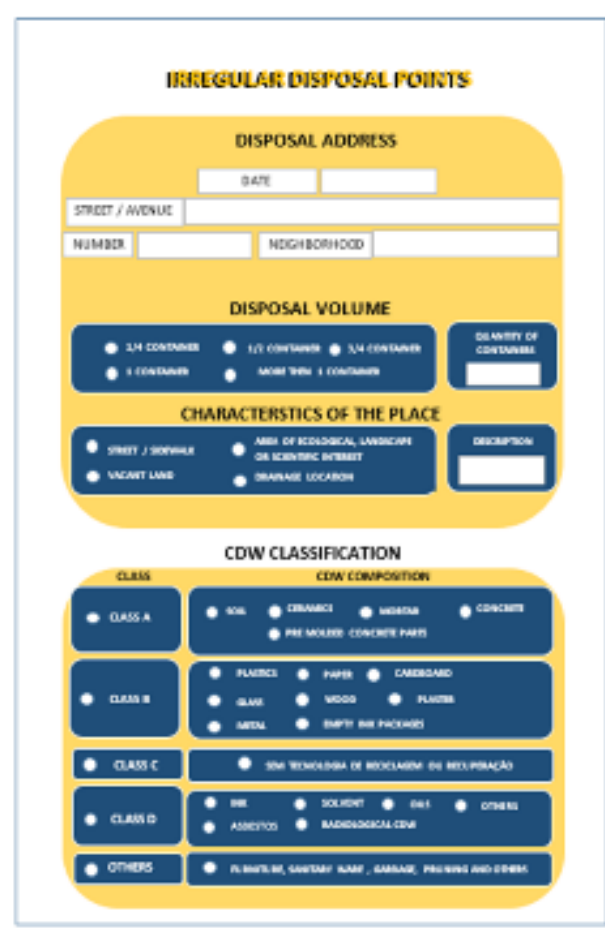

(b)

Figure 3 - (a) Internal division of a container with a volume of $5 \mathrm{~m}^{3}$, showing how much approximately $1 / 4$ container, $1 / 2$ container, $3 / 4$ container and 1 container are equivalent. (b) Form used to record information related to the inappropriate disposal sites. Source: The authors (2020).

Subsequently, the collected data were transcribed to a spreadsheet in the Excel software, for later elaboration of graphs for analysis. It is noteworthy that the georeferenced location of each point was marked using the GPS location sending function on the smartphone used. In addition to being stored in the mentioned spreadsheet, the georeferenced location was also transcribed to the Google Maps application, thus allowing the generation of a map with all the inappropriate disposal places.

\section{Data Analysis}

The analysis of the collected data was carried out from the elaboration of graphs of quantitative type, in order to obtain comparative information grouped by different parameters. The disposal points were quantified: 1) by neighborhood; 2) according to the location of the disposal: if it was carried out on vacant lots, public roads, areas close to drainage points and/or areas of ecological, landscape or scientific interest; 3 ) by CDW type; 4) according to the approximate volume of waste disposed $\left(\mathrm{m}^{3}\right)$.

These classifications and quantifications helped in the study of the affected areas and consequent recommendations for each neighborhood. The generation of graphs was performed using the dynamic graph resource available in Excel.

In order to identify the number of inadequate disposal occurrences in each neighborhood and the accumulated percentage of occurrences, the Pareto Chart was adopted. It is one of the seven quality tools, used to prioritize problems that demand a greater concentration of efforts for solution. This chart is based on the principle stated by Joseph Juran that $80 \%$ of a part's quality problems are caused by $20 \%$ of the types of defects. In this way, focusing on solving $20 \%$ of the origins of problems, a big improvement can be 
achieved with minimal effort. The Pareto Chart shows a cumulative percentage line, starting at the topmost bar on the left and ending on the right, showing the cumulative percentage of all problems (Best \& Neuhauser, 2006).

A comparative analysis was carried out aiming to evaluate, in a similar period of data collection, the differences in volumes, number of points and characteristics of the discharges between the 18 different neighborhoods. It should also be noted that a mapping of the disposal points was carried out with the support of the Google Maps application, in order to allow a broad visualization of their geographic distribution.

Finally, based on the achieved experience in the process of collecting data, a mobile support application was proposed and developed. Further, some recommendations for actions to address the problem were presented, stemming from the analysis of the inappropriate CDW disposal occurrences.

\section{Results and discussion}

\section{Analysis of illegal CDW discharges}

A total of 179 inadequate CDW disposal points were detected in the 18 neighborhoods. The registered points were marked on a map with the aid of the Google Maps application to enable the visualization of their distribution (Figure 4). The elaboration of the map can also assist in the planning and definition of possible drop off sites in order to generate more effective results for the waste management.



Figure 4 - Mapping of CDW inadequate disposal points in the neighborhoods. Source: The authors (2020).

The Pareto Chart (Figure 5a) shows that the five neighborhoods with the highest incidence of inappropriate disposal of CDW accumulate 79\% of the total dumped. These neighborhoods (Portinho, Braga, Palmeiras, Jardim Excelsior and Praia do Siqueira) have the following characteristics in common: they are predominantly residential neighborhoods, have vacant lots and are far from the center of Cabo Frio and the historic center. It is noteworthy that the city center is most frequented by tourists, where inspection tends to be more rigorous.

It should be noted that the territorial extension of each neighborhood must be observed, as larger neighborhoods may have a higher incidence of inappropriate disposal than smaller ones. Thus, a graph showing the number of points of inadequate disposal per $\mathrm{km}^{2}$ shows the neighborhoods where the incidence per surface area is highest (Figure $5 \mathrm{~b}$ ). The five neighborhoods that have the highest amount of disposal points per square kilometer are the same, but the order of relevance is changed. Thus, the priority 
Characteristics and patterns of inappropriate disposal of construction and demolition waste in the municipality of Cabo Frio, Brazil

of dealing with the problem of inappropriate disposal would become the sequence indicated in this figure. In this case, to eliminate approximately $80 \%$ of the points of inadequate disposal per $\mathrm{km}^{2}$, the nine most impacted neighborhoods in the graph must be prioritized.

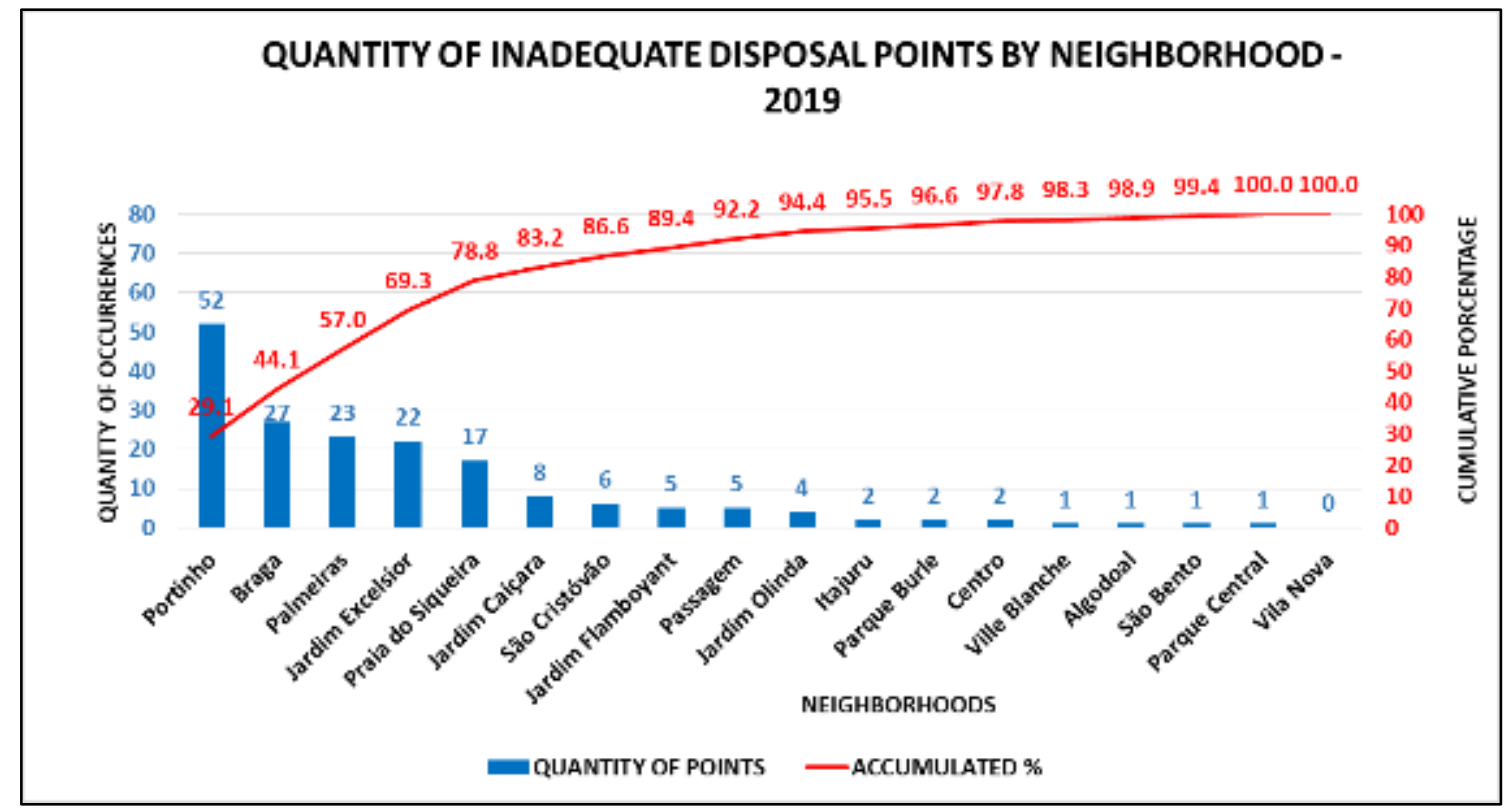

(a)

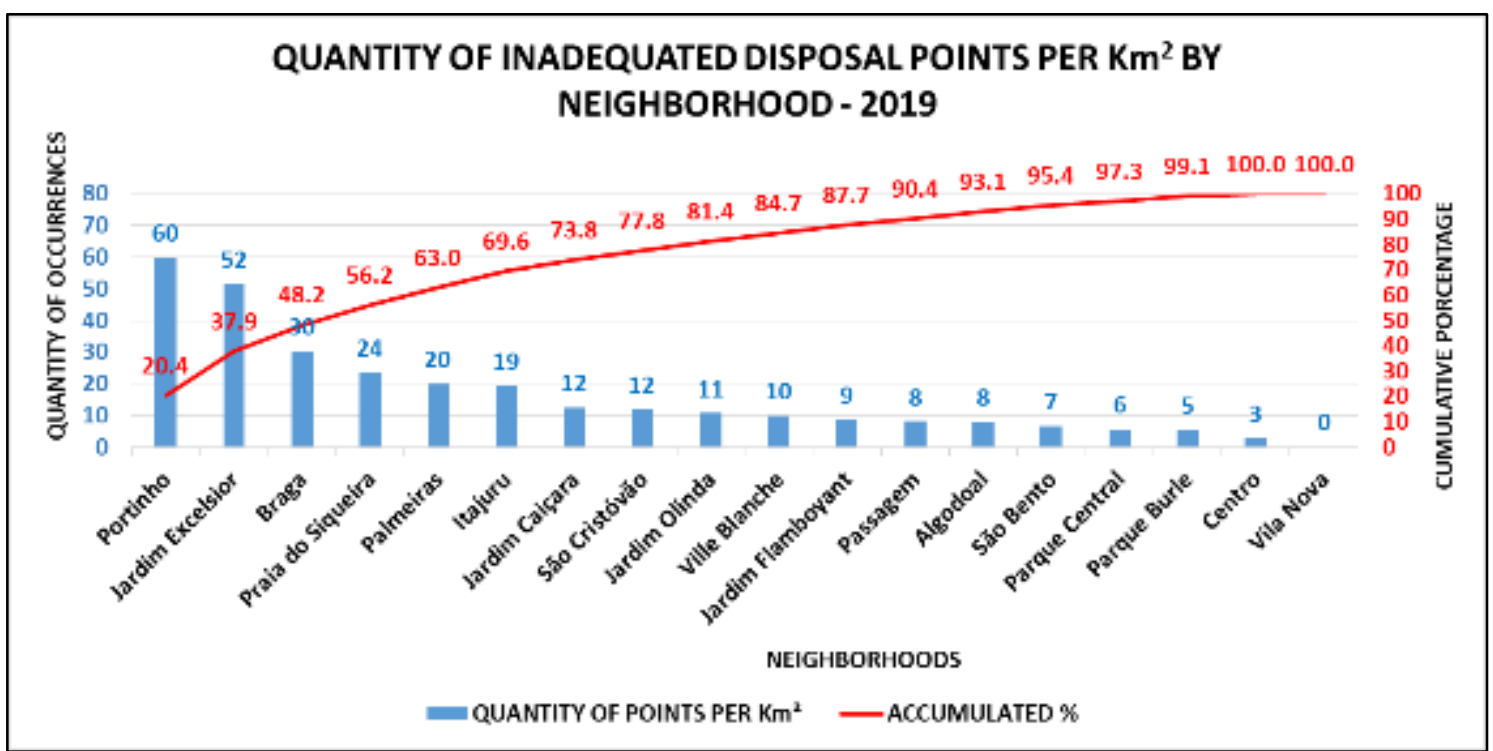

(b)

Figure 5 - (a) Pareto Chart with the number of occurrences per neighborhood and the cumulative percentage of occurrences.

(b) Pareto Chart with the number of occurrences per area in each neighborhood and the cumulative percentage of occurrences. Source: The authors (2020).

It is important to point out that the neighborhoods of the largest extension do not necessarily have the largest amount of points of inadequate disposal. The graph in Figure 6 shows the comparison between the surface area of each neighborhood and the amount of discard per $\mathrm{km}^{2}$. The biggest neighborhood, Palmeiras, is not the holder of the greatest amount of inappropriate disposal points, being surpassed by Portinho, Jardim Excelsior, Braga and Praia do Siqueira. It can also be seen that neighborhoods with considerable extension, such as Centro, for example, had a low occurrence of inappropriate disposal points per $\mathrm{km}^{2}$. 
Characteristics and patterns of inappropriate disposal of construction and demolition waste in the municipality of Cabo Frio, Brazil

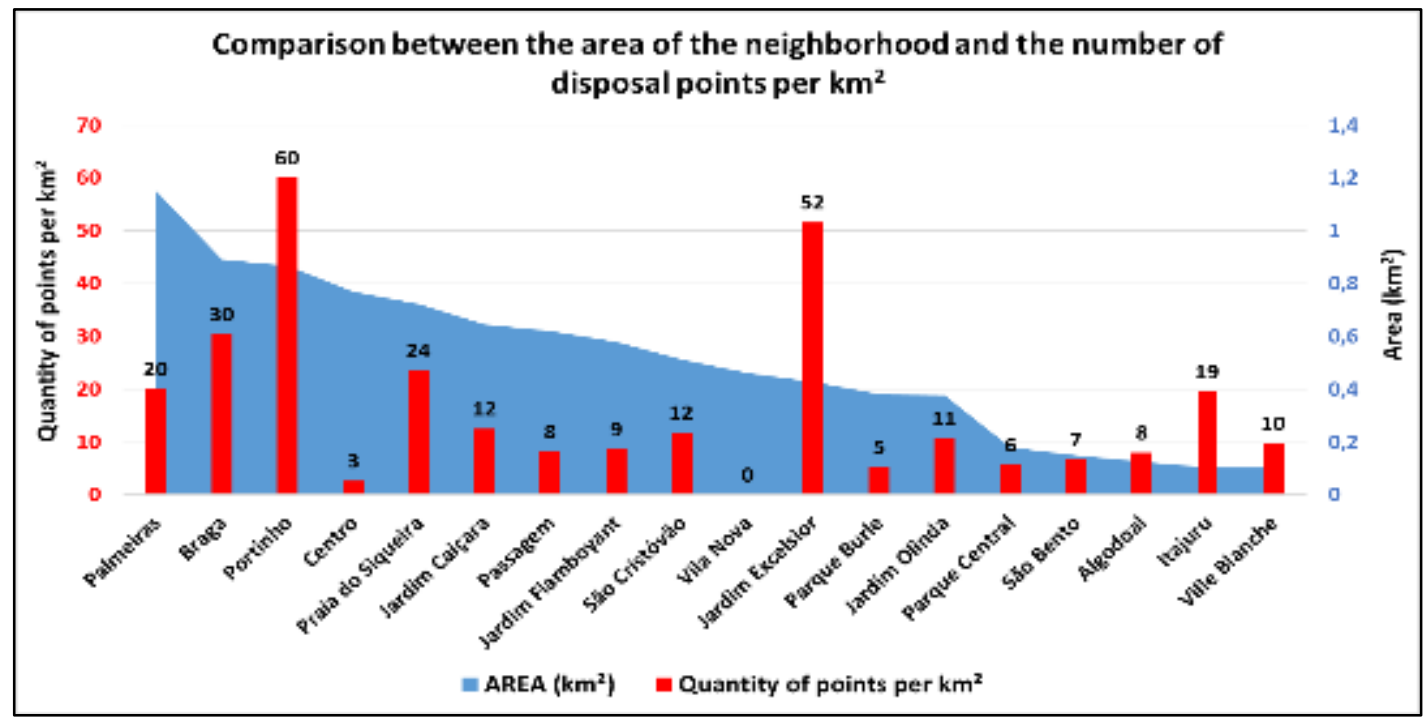

Figure 6 - Comparison between the area of each neighborhood and the quantity of disposal points per km². Source: The authors (2020).

Figure 7 shows the approximate volumes of CDW discarded, measured in $\mathrm{m}^{3}$, considering the use of a $5 \mathrm{~m}^{3}$ container as a reference. Vila Nova neighborhood was not shown because there were no occurrences there.

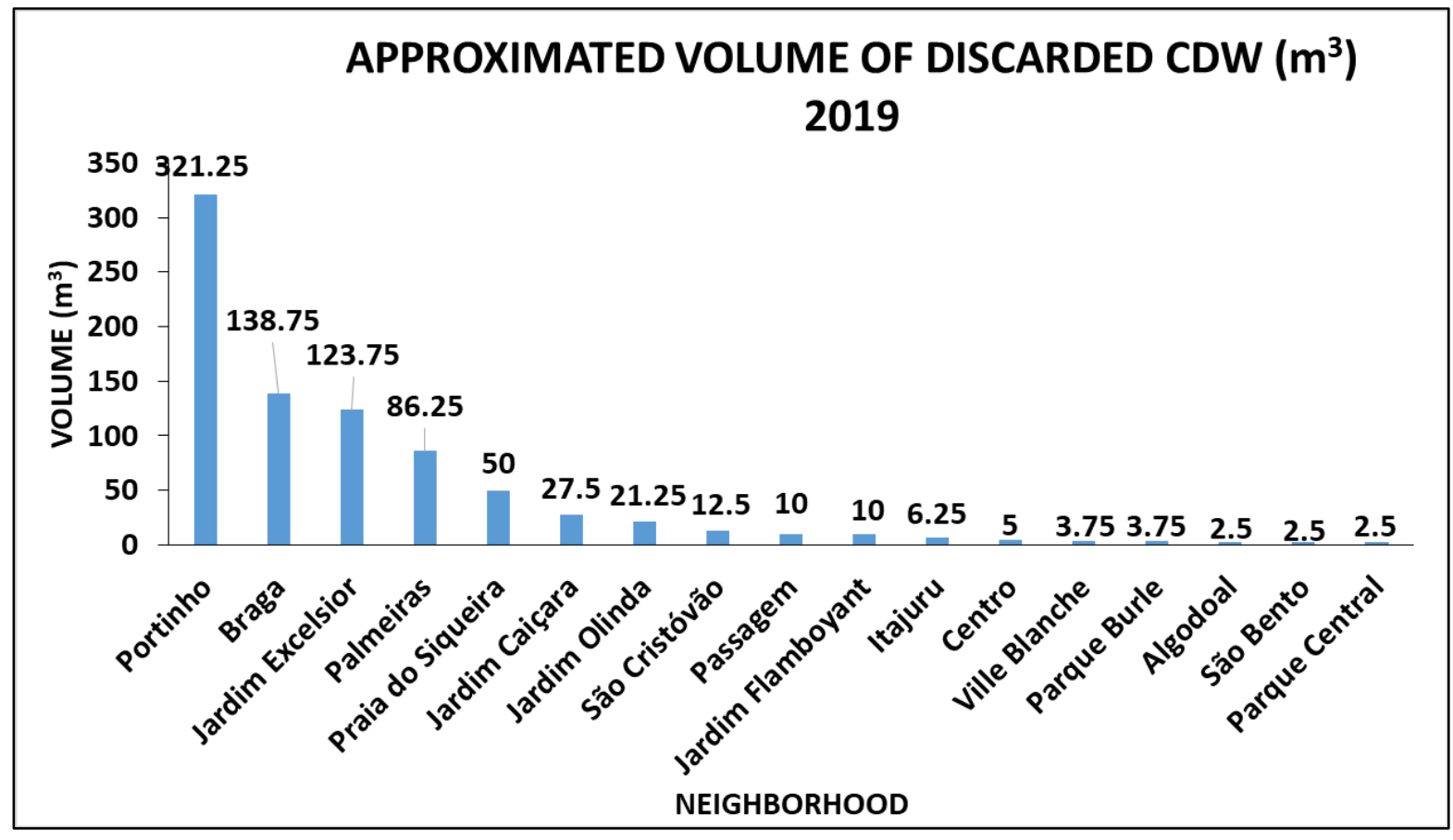

Figure 7 - Volume $\left(\mathrm{m}^{3}\right)$ of CDW discarded by neighborhood. Source: The authors (2020).

The neighborhoods with the highest incidence of CDW inappropriate disposal points are also the ones whose CDW volumes are more expressive. Portinho, Braga, Jardim Excelsior and Palmeiras neighborhoods currently have new real estate developments under construction, in addition to renovations.

Regarding the disposal sites, as shown in Figure 8a, there was inadequate disposal at 15 sites in areas of ecological, landscape or scientific interest ( $8.4 \%$ of the total), 5 discharges over drainage places, such as manholes and sewer grates (2.8\%), 92 located on public roads or sidewalks (51.4\%) and 79 on vacant lots (44.1\%). It should be noted that these variables are independent, and the same disposal point may include more than one type of location (e.g. both a manhole and a public road).

Most of the waste discarded in vacant lots was located at the Portinho neighborhood. Similarly, the neighborhoods Jardim Olinda and Parque Central only presented discharges in vacant lots. In the other neighborhoods, on the other hand, the majority of inadequate discharges were carried out on public roads 
and sidewalks. Centro, Itajuru and Ville Blanche neighborhoods, which have practically no vacant lots, had all the inadequate discharges made on the sidewalks. As Portinho neighborhood is undergoing an urbanization process, the number of constructions sites is greater. Consequently, there is a greater waste disposal. Further, as the neighborhood has a lot of vacant lots, the residents end up using these areas as dump sites, not complying with the National Environment Council Resolution 448 (CONAMA, 2012) in terms of the disposal of solid construction waste. Braga, Jardim Excelsior, Jardim Flamboyant and Passagem neighborhoods had discharges over manholes and sewer grates. It is noteworthy that the municipality of Cabo Frio presents flooding of the streets of several neighborhoods in rainy season. Its drainage system is affected by the irregular disposal of waste of all types, including CDW. Dump points were also identified in areas of ecological, landscape and scientific interest in the municipality. In Braga neighborhood, some dumpings were cataloged on the way to the Dunes. In Portinho, there was a large amount of waste in the mangroves, in addition to disposal on the banks of the Araruama Lagoon, in the Itajuru Canal and in the Sambaqui. In São Bento neighborhood, disposal was identified at São Bento Beach, bathed by the waters of the Itajuru Canal. In Praia do Siqueira there were discards by the Palmer Canal, at Siqueira beach and in the salt pan.

The waste was also classified according to its composition. The number of occurrences of each class of waste by neighborhood is shown in Figure 8b. A higher incidence of class A waste was observed in most neighborhoods, followed by a significant proportion of class B waste. Discards of class D waste were detected in Braga, Palmeiras and Praia do Siqueira. No class C waste was observed in any neighborhood. Other kinds of waste (e.g. household waste, pruning and unserviceable items, such as furniture and sanitary wares) were dumped in most neighborhoods. They may cause disease proliferation due mainly to the presence of organic residues, which favour the presence of synanthropic, venomous and diseasetransmitting animals.

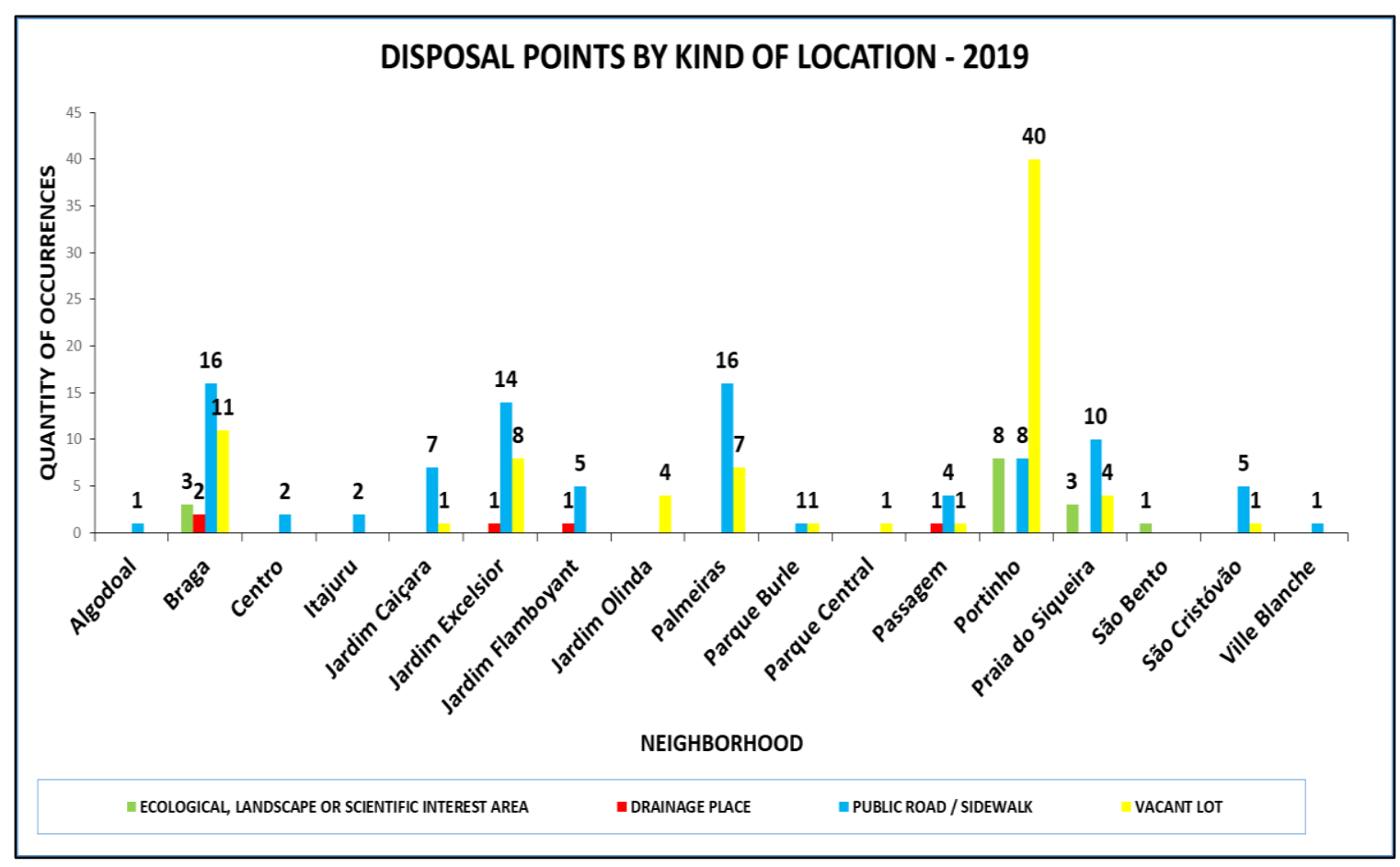

(a) 


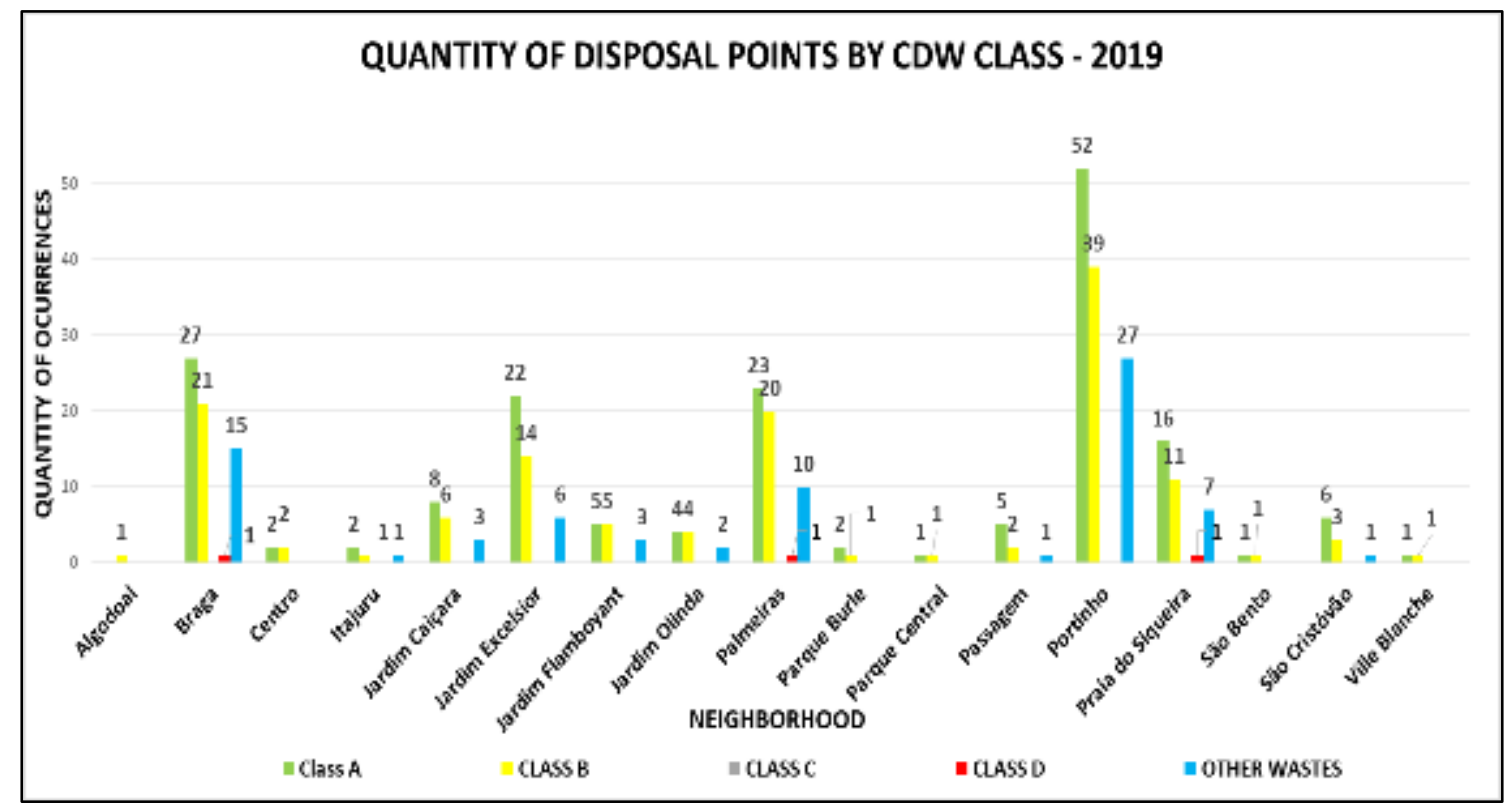

(b)

Figure 8 - (a) Quantity of disposal points by types of impacted location. (b) Number of occurrences by waste class. Source: The authors (2020).

\section{Support software}

During data collection, the difficulty of registering the information in real time was detected. So it was decided to develop a mobile application that could help marking the location of the CDW disposal site and recording its image, its estimated volume, its composition, and the main impacts generated on the environment.

Among the various features presented by the application it can be mentioned: integration with Google Maps and identification of the disposal location through the smartphone georeferencing mechanism; registration of the CDW disposal data (location, class of waste, type of material, characteristic of the place, volume, and image integrated to the smartphone camera); search for inappropriate disposals; import and export of data, including files in csv format that can be integrated with spreadsheets. Figure 9 shows the images of some forms from the application, which was developed in Portuguese language.

The first version of the software was developed in Portuguese. There are plans to develop a future version in English, which may increase the coverage of the tool. It is believed that this application may streamline the work of researchers and inspection agents, by allowing information to be recorded and consolidated reliably and in real time. 


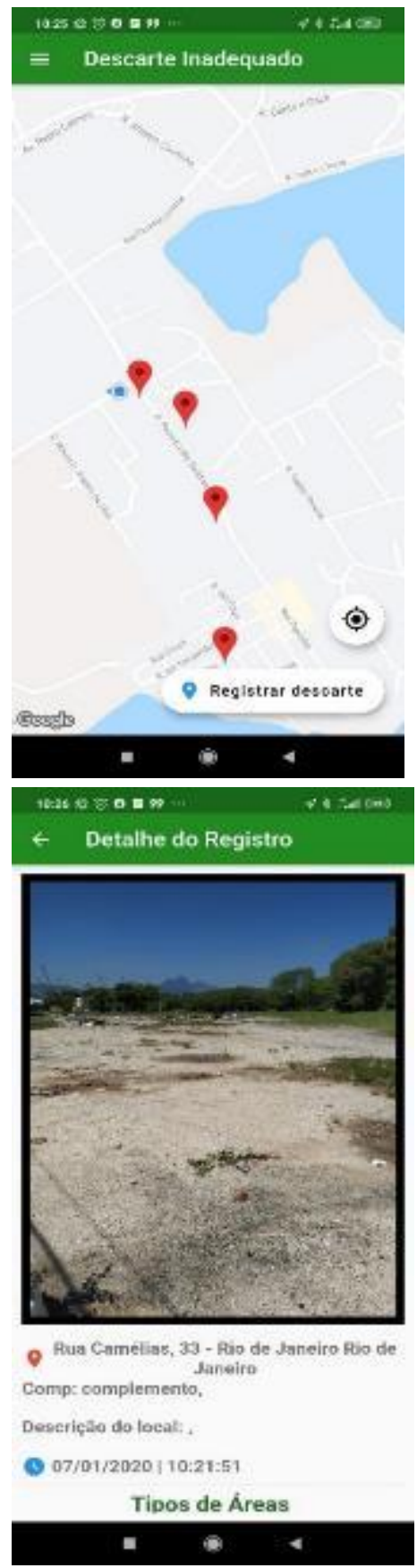

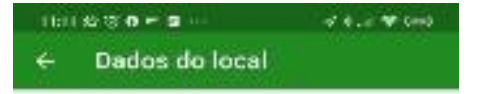

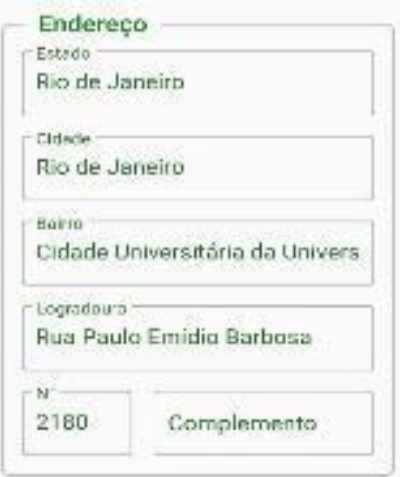

Descric:so do locel

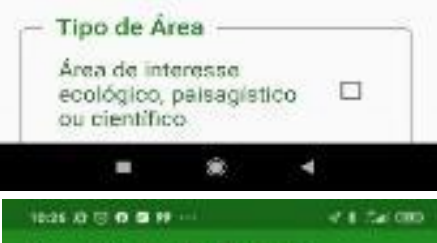

\section{$\leftarrow$ Detalhe do Registro}

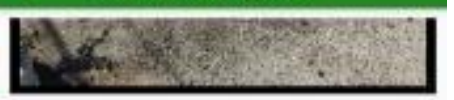

Q Flua Camellas, 33 - Rio de Janeiro Rlo de

Comp: complemento, Janeiro

Descriçào do local: ,

C 07/01/2020110:21:51

23. Terreno Baldio

Tipos de Classes

A

Tipos de materiais
Ceramicos
Peças pre - moldadas em eoncruto;
Caçambas: $4.0 \mathrm{m3}$

Caçambas: $4.0 \mathrm{m3}$
Volume: $20.0 \mathrm{~m}^{3}$

Latitude: -22.8692038 Longitude: -43.218384

Nas:

Goinle val CAN

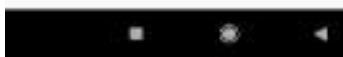

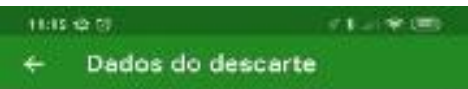
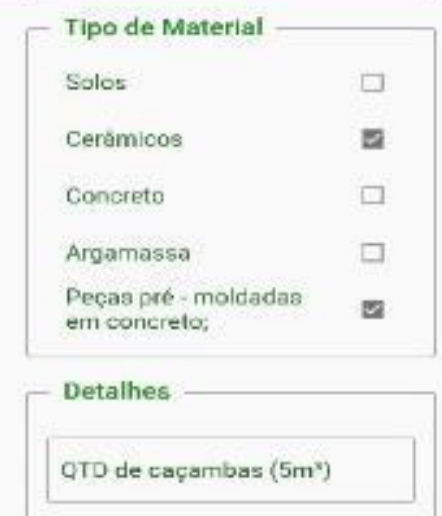

Caracteristica da disposiçào.

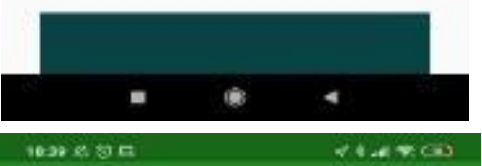

$\leftarrow \quad$ Importar e exportar dados

. Gerar CSV dos registros

$\uparrow$ Exportar dados

(importar dados

Figure 9 - Mobile App Forms. Source: The authors (2020).

\section{Suggested actions}

Based on the analysis of the collected information, some actions aimed at reducing the inappropriate disposal of CDW are proposed. Because the data collection was restricted to Cabo Frio, the actions to solve the problem were directed, in principle, to the authorities of that municipality. Although these actions were thought based on the specific reality of Cabo Frio municipality, the ideas can be adapted to other regions by taking the regional particularities into account.

Action 1: Implement an itinerant waste collection schedule for dealing with small volumes, based on the neighborhoods with the highest occurrence rate and on forecasts for future construction works

Currently, Cabo Frio offers the service of collecting small volumes of CDW through COMSERCAF (Public Service Company of Cabo Frio). In addition to collecting construction waste, the collection of pruning and 
unserviceable items, such as furniture and sanitary wares, is also carried out by the service provider. For this to happen, currently the population needs to pack the waste in 200 litres bags.

COMSERCAF has a legal obligation to collect $3 \mathrm{~m}^{3}$ of waste by address. In this way, CDW disposal sites registered as having up to $1 / 2$ waste container could be eliminated through this service. Thus, improvement in inspection and dissemination of the service provided by COMSERCAF would considerably reduce the number of small points of inappropriate disposal.

In addition to disclosure and inspection, planning is essential for the action to be effective. In this sense, the present study can assist in the definition of priority neighborhoods. In the mapping carried out, 62 points with $1 / 4$ of discarded waste container and 57 points with $1 / 2$ container were detected. The biggest holders of small volumes of waste were Portinho, Palmeiras, Jardim Excelsior, Braga and Praia do Siqueira neighborhoods. The sites to be prioritized in these neighborhoods must be those one identified as impacting drainage areas and areas of ecological, landscape or scientific interest.

Action 2: Inspection of construction projects close to the higher volume disposal sites

For large volumes, generators must hire containers to collect these materials. Inspection of works in progress close to the large volumes' disposal points can prevent the irregular dumping of some generators. For dumping private areas whose waste generators are not identified in the surroundings, the owner of the land could be identified by the city hall and assessed, with the requirement of cleaning and delimitation of the land. For public land, the city could remove the waste with the help of the services provided by COMSERCAF. According to this study, the neighborhoods with the highest incidence of large volumes are Portinho, Braga and Jardim Excelsior. Priority should be given to locations in these neighborhoods that have been identified as being harmful to drainage areas and areas of ecological, landscape or scientific interest.

Action 3: Conduct a study for implementation of drop off sites

Resolution 307 (CONAMA, 2002) mentions that municipalities must maintain a register of public or private areas suitable for receiving, sorting and temporary storage of small volumes. In fact, the installation of drop off sites benefits the population in their surroundings, as it facilitates the disposal of waste in an appropriate place, instead of carrying out clandestine evictions in inappropriate places. The installation of drop off sites allows the segregation of inert waste before its final disposal. In this way, the rate of recycled materials can increase, and consequently the useful life of landfills as well.

Therefore, a project to implement drop off sites in the municipality is necessary to allow the receiving of small volumes of CDW, to provide areas for transhipment of the waste collected by urban cleaning services, and for sorting of inert materials and temporary storage. It is worth mentioning that an economic feasibility analysis can assist in making decisions about the installation of fixed drop off sites, itinerant drop off sites or a mixture of both types. The mapping of inadequate disposal points can help in defining the most suitable locations for the implementation of drop off sites, but the registration of suitable areas, carried out by the city hall, should also be considered. Thus, the neighborhoods with the highest number of irregular disposal points (Portinho, Braga, Palmeiras, Jardim Excelsior and Praia do Siqueira) could be the first to be considered, as they have suitable land for that purpose. For the success of drop off sites implementation, environmental education and inspection programs must take place in parallel.

\section{Action 4: Conduct an environmental education program}

Another requirement of Resolution 307 (CONAMA, 2002) is the implementation of educational actions focused on reducing the generation of waste and its segregation. In fact, for these actions to be successful, the environmental education process must involve the inspectors, the population, the large generators, the waste collectors, the recipients, in short, all affected parties. Wide and intense disclosure should be made on how and where to properly dispose of waste, reaching small and large generators; only in this way the implemented drop off sites can present satisfactory results. Awareness campaigns need to be carried out, pointing out the drainage problems, aggravated in the municipality by the waste discarded near the 
manholes. Besides, alerting for the contamination risks that the disposal of class D CDW can generate when done at drainage of rainwater, in the soil and in water courses. It is also necessary to disclose that the mixture of hazardous waste with recyclable waste reduces the possibility of reusing the aggregates because they are contaminated. Another important issue is the awareness that the disposal of household waste with CDW facilitates the proliferation of disease transmitters, venomous and synanthropic animals, affecting public health.

Action 5: Create a preventive inspection program

Implementation of a rigorous inspection program that is not only corrective, but that includes preventive actions, addressing the requirements of Resolution 307 (CONAMA, 2002), such as: 1) Request large generators to present their CDW Management Projects, containing technical guidelines and procedures, prior to the authorization of their ventures; 2) Establish contracts only with processing companies and landfills for final disposal of waste that are licensed, as well as for transporters, controlling the validity of these licenses; 3 ) Create tax incentive policies for generators that include the use of reusable or recycled waste in their production processes; 4) Periodically inspect small and large generators, guiding and encouraging the use of drop off sites and legally punishing those responsible for clandestine discharges, in order to curb irregularities.

\section{Conclusions}

When comparing the different regions investigated in this work, there was a greater occurrence of CDW inadequate disposal in residential neighborhoods with vacant lots which were located away from the center of Cabo Frio and the historic center. It was observed the occurrence of small volumes of disposal in practically all neighborhoods, originated from small reforms and occasional repairs. Large volumes predominate in residential neighborhoods, occurring to a lesser extent in mixed neighborhoods, which have commercial establishments mixed with residences. Disposals were also recorded in areas of environmental, landscape and scientific importance as well as on manholes and sewer grates. There was a predominance of class A CDW followed by class B CDW, in addition to the constant presence of household waste, waste and pruning mixed with rubble. Thus, recyclable aggregates need prior separation to be reused. In addition, in neighborhoods that contained older buildings there was an inadequate arrangement of asbestos tiles, classified as class D CDW.

One contribution of this work was the discussion of results related to the municipality of Cabo Frio, accompanied by the suggestion of actions to the public authorities. Despite addressing one municipality, these suggestions can be adapted and applied in other regions as well. Another contribution was the proposal of a methodology for surveying and analyzing situations of inappropriate disposal of CDW. The development of a smartphone application for use by inspection agents and/or researchers concerned with the issue can also be considered a relevant contribution. This tool can facilitate the registration of data and the generation of information to assist decision making by actors involved in the waste management process.

It is worth highlighting the importance of developing, in future works, an analysis of the relationship of the volume of waste irregularly disposed per inhabitant, based on a survey of populations stratified by neighborhood. A deep analysis of the socioeconomic profile of the populations is recommended. This approach could assist decision making, by indicating priority areas for carrying out environmental education projects. The type of CDW generation (new construction, repair/rehabilitation, demolition etc) may also be included in future analyses, since these parameters also influence the behavior of user thereby influence the dump pattern. This information was not considered in this work due to the uncertainty related to the waste generators. Some vacant lots, for example, contained older waste mixed with recent disposals, apparently discarded by more than one (unknown) generating source.

It is also suggested, for future research, in addition to collecting data from all neighborhoods in the municipality of Cabo Frio, the wide dissemination of this information to the community. Thus, environmental 
education campaigns could be planned by neighborhood, based on the survey of the most impacted areas. The awareness of small and large generators regarding the classes of CDW must be worked on, aiming at a successful implementation of drop off sites. Besides, the inspection must be not only corrective, but mainly preventive in order to curb irregular discharges and thus promote the success of the program.

\section{Acknowledgements}

This work was supported by FUNADESP — National Foundation for the Development of Private Higher Education.

\section{References}

Abhijith, H., Sreejith, M. H., Priya, A. J., \& Aiswarya, S. (2014). Minimizing Construction Wastes By Efficient Site Practices. IJEAR - International Journal of Education and applied research, 4(2), 46-48. http://ijear.org/vol4/spl2/ec0040.pdf.

Akhtar, A., \& Sarmah, A. (2018). Construction and demolition waste generation and properties of recycled aggregate concrete: A global perspective. Journal of Cleaner Production, 186, 262-281. https://doi.org/10.1016/j.jclepro.2018.03.085.

Bertucci, T. C. P., Silva, E. P., Marques JR, A. N., \& Monteiro Neto, C. (2016). Turismo e urbanização: os problemas ambientais da Lagoa de Araruama-Rio de Janeiro (Tourism and urbanization: the environmental problems of Araruama Lagoon - Rio de Janeiro). Ambiente \& Sociedade, São Paulo, 19(4), 43-64. https://doi.org/10.1590/1809-4422asoc137111v1942016.

Bessa, S. A. L., Mello, T. A. G., \& Lourenço, K. K. (2019). Quantitative and qualitative analysis of the construction and demolition waste generated in Belo Horizonte/MG. urbe. Revista Brasileira de Gestão Urbana, 11. https://doi.org/10.1590/2175-3369.011.e20180099.

Best, M., \& Neuhauser, D. (2006). Joseph Juran: overcoming resistance to organisational change. Quality \& safety in health care, 15(5), 380-382. https://doi.org/10.1136/qshc.2006.020016.

Brasil. Ministry of Tourism. (2018). Brazilian tourism map 2017. Brasília: Ministério do Turismo. Retrieved on November 12, 2018, from http://dados.gov.br/dataset/mapa-do-turismo-brasileiro.

Brazilian Association of Public Cleaning and Special Waste Companies - ABRELPE. (2019). Overview of Solid Waste in Brazil 2018/2019. São Paulo: ABRELPE. Retrieved on January 15, 2020, from https://abrelpe.org.br/download-panorama-2018$2019 /$.

Conselho Nacional do Meio Ambiente - CONAMA. (2002). Resolução 307, de 5 de julho de 2002. Estabelece diretrizes, critérios e procedimentos para a gestão dos resíduos da construção civil. (National Environment Council of Brazil Resolution 307, 5 jul 2002 - Establishes guidelines, criteria and procedures for the management of construction waste). Diário Oficial da União, nº. 136.

Conselho Nacional do Meio Ambiente - CONAMA. (2012). Resolução 448, de 18 de janeiro de 2012. Adequação da Resolução $307 / 2002$ aos mecanismos da Lei 12.305/2010 que ordena a Política Nacional de Resíduos Sólidos (National Environment Council of Brazil - Resolution 448, 18 jan 2012 - Adequacy of Resolution 307/2002 to the mechanisms of Law 12.305 / 2010, which regulates the National Solid Waste Policy). Diário Oficial da União, nº. 14.

Costa, E. D. C. P., Costa, A. C. D. C. P., \& Correio, F. D. J. N. (2017). A importância de políticas públicas ambientais em Cabo Frio-RJ: uma perspectiva interdisciplinar (The importance of public environmental policies in Cabo Frio - RJ: An interdisciplinary perspective). Revista de Trabalhos Acadêmicos - Universo Juiz de Fora, 1 (6). Retrieved on November 25 , 2018, from

http://www.revista.universo.edu.br/index.php?journal=1JUIZDEFORA2\&page=article\&op=view\&path\%5B\%5D=3712 .

Cruz, E. G. B., Oliveira, O. S., \& Cruz, M. F. G. (2017). Identificação e mapeamento de pontos de disposições irregulares de resíduos sólidos no perímetro urbano do município de Humaitá-AM (Identification and mapping of solid waste irregular points in urban perimeter of humaitá municipality - Amazonas). Revista Gestão e Sustentabilidade Ambiental, Florianópolis, 6(2), 184-201. http://dx.doi.org/10.19177/rgsa.v6e22017184-201.

Department of Environment, Food and Rural Affairs - DEFRA. (2015). Digest of Waste and Resource Statistics. UK Government: DEFRA. Retrieved on February 24, 2019, from https://assets.publishing.service.gov.uk/government/uploads/system/uploads/attachment_data/file/482255/Digest_of_ waste_England_-_finalv3.pdf. 
Duan, H., \& Li, J. (2016). Construction and demolition waste management: China's lessons. SAGE journals, 34(5), 397-398. https://doi.org/10.1177/0734242X16647603.

Gulghane, A. A., \& Khandve, P. V. (2015). Management for construction materials and control of construction waste in construction industry: a review. International Journal of Engineering Research and Applications, 5(4), 59-64. Retrieved on March 27, 2019, from https://www.semanticscholar.org/paper/Management-for-Construction-Materials-and-Control-AGulghane-Khandve/c27f7deec93020a8cdfdb67c7651ba8398e23e49?p2df.

Huang, B., Wang, X., Kua, H., Geng, Y., Bleischwitz, R., \& Ren, J. (2018). Construction and Demolition Waste Management in China through the 3R Principle. Resources Conservation and Recycling, 129, 36-44.

https://doi.org/10.1016/j.resconrec.2017.09.029.

Jain, S., Singhal, S., \& Jain, N. K. (2018). Construction and demolition waste (C\&DW) in India: generation rate and implications of C\&DW recycling. International Journal of Construction Management, 1-10.

https://doi.org/10.1080/15623599.2018.1523300.

Lorena, E. M. G., Bezerra, A. P. X. G., Gabriel, F. A., Silva, M.C., Marinho, G. P. A., \& Holanda, R. M. (2017). Diagnosis of the inadequate disposal of construction and demolition waste in Vitória de Santo Antão, Pernambuco. Rev. Geama, Recife, 3 (1), 23-28. Retrieved on April 28, 2019, from http://www.journals.ufrpe.br/index.php/geama/article/view/1165.

Lu, W. (2019). Big data analytics to identify illegal construction waste dumping: A Hong Kong study. Resources, Conservation and Recycling, 141, 264-272. https://doi.org/10.1016/j.resconrec.2018.10.039.

Mah, C. M., Fujiwara, T., \& Ho, C. S. (2018). Environmental impacts of construction and demolition waste management alternatives. Chemical Engineering Transactions, 63, 343-348. https://doi.org/10.3303/CET1863058.

Marzouk, M., \& Azab. S. (2014). Environmental and economic impact assessment of construction and demolition waste disposal using system dynamics. Resources, Conservation and Recycling, 82, 41-49.

https://doi.org/10.1016/j.resconrec.2013.10.015.

Ministère de la Cohésion des Territoires et des Relations Avec les Collectivités Territoriales - MCTRACT. (2019). Déchets du bâtiment. Retrieved on february 12, 2020, from http://www.cohesion-territoires.gouv.fr/dechets-du-batiment.

Paz, D. H. F. D., Lafayette, K. P. V., \& Sobral, M. D. C. (2018). GIS-based planning system for managing the flow of construction and demolition waste in Brazil. Waste Management \& Research, 36(6), 541-549.

https://doi.org/10.1177/0734242X18772096.

Peralta, E. M. C. N. (2011). Land and access to housing in Cabo Frio: the difficulties in implementing the urban planning instruments of the city statute (Specialization's Monograph). Faculty of Urban Engineering, Federal University of Rio de Janeiro, Rio de Janeiro.

Plano Estadual de Resíduos Sólidos do Rio de Janeiro - PERS. (2013). Plano Estadual de Resíduos Sólidos do Rio de Janeiro (Rio de Janeiro State Solid Waste Plan). Retrieved on November 24, 2017, from

http://www.rj.gov.br/c/document_library/get_file?uuid=65e25795-833b-4eef-acb2-9d29da85b1c6\&groupId=132946.

Prefeitura Municipal de Cabo Frio - PMCBF. (2006, 07 de dezembro). Lei complementar no. 4 de 07 de dezembro de 2006. Institui o novo Plano Diretor Municipal de Desenvolvimento Sustentado, estabelece objetivos, instrumentos e diretrizes para as ações de planejamento no Município de Cabo Frio, e dá outras providências (Cabo Frio City Hall. Complementary law no. 4 December 7, 2006. Institutes the new Municipal Master Plan for Sustainable Development, establishes objectives, instruments and guidelines for planning actions in the Municipality of Cabo Frio, and takes other measures). Retrieved on October 28, 2019, from http://webservice.npibrasil.com.br/wportal/arquivo.ashx?id=87d10859-a02d-4dba-b21d7676155 eecde.

Prefeitura Municipal de Cabo Frio - PMCBF. (2019). Pontos Turísticos. Portal da Prefeitura de Cabo Frio. Cabo Frio, Rio de Janeiro, 2019 (Cabo Frio City Hall. Attractions. Cabo Frio City Hall Portal. Cabo Frio, Rio de Janeiro, 2019). Retrieved on December 11, 2019, from http://cabofrio.rj.gov.br/turismo/pontos-turisticos/.

Sáez, P. V., \& Osmani, M. (2019). A diagnosis of construction and demolition waste generation and recovery practice in the European Union. Journal of Cleaner Production, 241, 118400. https://doi.org/10.1016/j.jclepro.2019.118400.

Schuindt, R. M. A., Daco, R. S., \& Oliveira, M. M. (2018). Impactos na Lagoa de Araruama e percepção ambiental da comunidade da Praia do Siqueira, Cabo Frio (RJ) (Impacts on Araruama Lagoon and environmental perception of the Praia do Siqueira community, Cabo Frio (RJ)). Revista Brasileira de Educação Ambiental (RevBEA), São Paulo, 13(1), $299-321$. https://doi.org/10.34024/revbea.2018.v13.2475 . 
Secretaria de Estado do Ambiente - SEA. (2013). Governo do Estado do Rio de Janeiro. Consultoria e Assessoria Técnica de Engenharia à SEA para Elaboração de Plano Estadual de Resíduos Sólidos (PERS), Volume 2: Diagnóstico dos Resíduos Sólidos - Tomo I (State Secretariat for the Environment - Government of the State of Rio de Janeiro. Engineering Consultancy and Technical Assistance to SEA for Elaboration of the State Solid Waste Plan (PERS), Volume 2: Diagnosis of Solid Waste). Retrieved on October 10, 2019, from https://docplayer.com.br/3783832-Consultoria-e-assessoria-tecnica-de-engenhariaa-sea-para-elaboracao-do-plano-estadual-de-residuos-solidos-pers.html.

Seror, N., \& Portnov, B. A. (2018). Identifying areas under potential risk of illegal construction and demolition waste dumping using GIS tools. Waste Management, 75, 22-29. https://doi.org/10.1016/j.wasman.2018.01.027.

United States Environmental Protection Agency - U.S. EPA. (2018). Construction and Demolition Debris Generation in the United States, 2015. Retrieved on February 24, 2019, from https://www.epa.gov/sites/production/files/201809/documents/construction_and_demolition_debris_generation_in_the_united_states_2015_final.pdf.

Zainun, N. Y., \& Othman, W. (2015). Quantification and Mapping of Construction Waste Generation in Parit Raja. Applied Mechanics and Material, 773-774, 1032-1036. https://doi.org/10.4028/www.scientific.net/AMM.773-774.1032.

Zainun, N. Y., Rahman, I. A., \& Rothman, R. A. (2016). Mapping of Construction Waste Illegal Dumping Using Geographical Information System (GIS). IOP Conference Series: Materials Science and Engineering, 160(1), 12049-12056.

https://doi.org/10.1088/1757-899X/160/1/012049.

Editor: Paulo Nascimento Neto

Received: Mar. 25, 2020

Approved: Nov. 20, 2020 